\title{
TEACHERS' SELF-EFFICACY BELIEFS AND OPINIONS ABOUT DISTANCE EDUCATION DURING THE COVID-19 PANDEMIC
}

\author{
Dr. Yasemin TAS \\ ORCID: 0000-0002-3553-8711 \\ Kaziim Karabekir Faculty of Education \\ Ataturk University \\ Erzurum, TURKEY \\ Selma EMINOGLU \\ ORCID: 0000-0001-7770-4047 \\ Ministry of Education \\ Agri, TURKEY \\ Gulsah ATILA \\ ORCID: 0000-0002-3743-5222 \\ Ministry of Education \\ Erzurum, TURKEY \\ Yasemin YILDIZ \\ ORCID: 0000-0001-6497-8989 \\ Kazim Karabekir Faculty of Education \\ Ataturk University \\ Erzurum, TURKEY \\ Ummugulsum BOZKURT \\ ORCID: 0000-0001-6733-9816 \\ Kazim Karabekir Faculty of Education \\ Ataturk University \\ Erzurum, TURKEY
}

Received: 20/11/2020 Accepted: 08/04/2021

\begin{abstract}
This study investigated teaching self-efficacy beliefs and opinions about distance education of teachers in Turkey who switched to distance education during the COVID-19 pandemic. 758 teachers from Turkey completed an online questionnaire comprising demographic information questions, likert type scale items on self-efficacy for distance education, closed-ended questions addressing teachers' opinions about distance education, and an open-ended question enabling teachers express their experiences with distance education. Data analysis included descriptive statistics, independent samples t-tests, and content analysis. The analysis showed that teachers' beliefs in their own abilities in fulfilling the requirements of distance education, such as organizing effective learning environments and preparing different evaluation activities were not at a high level. The education they received, the active use of technology before the pandemic period and the type of school they work in have effects on teachers' self-efficacy towards distance education. The low number of students attending the live classes negatively affected their motivation. Furthermore, teachers thought that current instructional materials on the platform were not sufficient for students to be successful. However, teachers believed that their experiences in distance education during the pandemic increased their efficiency in education. Most participants received sufficient support from the school administration, but not from
\end{abstract}


parents during this period. Students' lack of computers and/or internet and systemic errors were among the main problems encountered by the teachers regarding the distance education system. In the study, suggestions were made to make distance education more effective.

Keywords: Distance education, teachers' self-efficacy beliefs, COVID-19 pandemic.

\section{INTRODUCTION}

In parallel with the developing pace of technology, changes have occurred in education as in many areas. The development of computer technologies and the transfer of information through the internet have started to occur rapidly. Considering today's education system, it has become evident that various technologies should be utilized and even these technologies should support education. The speed in the production and consumption of knowledge has taken learning out of the understanding of having a fixed space and time, making it possible to learn anytime and anywhere. With the advancing technology, this situation has become increasingly widespread, and in line with the emerging needs, the concept of distance education, which provides equality to people living in different geographies in different conditions, and gives flexibility in space and time, has come to the fore (Aydin, 2017; Bicer, 2019). Distance education, which has many definitions in the literature, is a teaching-learning system that is carried out regularly individually or in groups, where students and teachers in different environments and specially prepared teaching materials are brought together by means of communication technologies (Holmberg, 1995; Isik, Isik, \& Guler, 2008). Considering today's conditions, the reason why the concept of distance education has become widespread worldwide is the pandemic period caused by COVID-19.

The first COVID-19 case was reported in China on December 8, 2019 (Wu \& McGoogan, 2020) and has since spread almost worldwide. At the time of the article's submission, a total of over 83 million cases were reported in 195 countries worldwide (Digital Transformation Office, 2021). This pandemic has required a dramatic paradigm shift regarding our interactions with each other (Schneider, 2020). One of the first precautionary actions taken in order to control the situation in previous pandemics is the closure of schools (Hens et al., 2009). In the COVID-19 pandemic, many countries have also decided to close schools (Sahu, 2020; Viner et al., 2020; Wang et al., 2020). While some countries preferred to postpone the spring semester of the 2019-2020 academic year to the next semester, some countries chose to use systems that enable distance education to continue education (Domenico et al., 2020; Viner et al., 2020).

In this process, the biases and attitudes of teachers and students who are used to face-to-face education affect their distance education experiences. Difficulties may arise due to problems such as students and teachers not being competent enough in technology and lack of infrastructure in platforms offering distance education. Administrators with insufficient experience and knowledge in this area may have limited support for teachers and students. On the other hand, administrators who are open to technological developments can lean towards distance education and lead the way in interacting with individuals in online environments (Telli Yamamoto \& Altun, 2020).

This unplanned and unprecedented crisis towards society and education has suddenly and in many ways altered the work of many teachers (Fagell, 2020; Pirtle, 2020). During this period, school buildings were closed, and education moved to the online platform (Van Lancker \& Parolin, 2020). Teachers had to move quickly to unconventional teaching methods and find ways to communicate with their students. Whether referred to as distance learning, online or virtual learning, teachers have had a hard time providing meaningful educational experiences to all their students in this process (De Witt, 2020; Merrill, 2020). These types of learning and teaching are not new but are new to many teachers, and teacher's roles have changed during the crisis. Being forced to work from home, the fact that the existing lesson plans were not enough anymore, being forced to learn new technologies quickly, and being separated from their students, many teachers have experienced the most traumatic and transformational event of the modern age (Baired, 2020).

One of the important motivational concepts about teachers is teachers' self-efficacy beliefs. Teachers' selfefficacy beliefs are teachers' judgments about their ability to fulfil teaching-related tasks (Tschannen-Moran, Woolfolk Hoy, \& Hoy, 1998). Teachers' self-efficacy beliefs are very important, as they are closely related to 
teaching behaviours like using various teaching methods (e.g. Woolfolk, Rosoff, \& Hoy, 1990) and student outcomes like an academic achievement (e.g. Caprara, Barbaranelli, Steca, \& Malone, 2006). Factors such as the education teachers receive (Ross, 1994) and the support they receive from school administration (Larrick, 2004) have an effect on their self-efficacy beliefs.

Due to the COVID-19 outbreak, teachers had long-term distance education experience during this period. In this context, the need to examine teachers' self-efficacy beliefs about distance education has emerged. The purpose of this study is to determine the level of teachers' self-efficacy in distance education in Turkey, one of the countries making the transition to distance education due to the pandemic and to determine whether teachers' self-efficacy is affected by factors such as the education they receive, the type of school they work, the school administration and the support from parents. In addition, it was aimed to examine teachers' views on distance education and how they were affected by distance education.

\section{Distance Education}

The distance education approach was actually applied by some organizations in the United States of America in the 19th century by using a correspondence teaching tool. At the beginning of the 20th century, several major universities in Australia started distance education. Towards the end of the 20th century, distance education practices were also seen in Asian, African and South American countries. Today, depending on the development of belief in education, the spread of democracy and the advancement of technology, distance education is significantly developed and widely applied all over the world (Ozer, 1999).

In Turkey, the first open education faculty at university level was established within Anadolu University in 1982 (Anadolu University, 2021). In the 1990s, internet and web technologies came to the fore more, and distance education applications became much more comprehensive with the advantages of the internet (Kirik, 2014). In 2000, the first distance education courses accredited by Council of Higher Education were opened in Middle East Technical University and Firat University (Varol, 2001). Today, nearly 80\% of the existing higher education institutions in our country provide education at various certificate, associate degree, undergraduate and graduate levels with distance education practices (Ozbay, 2015) and distance education has been implemented widely in middle school, high school and higher education (Cukadar \& Celik, 2003).

The distance education process is student-centred, and there is a cooperation between the teacher and the student in this process. Students contribute to their own learning by taking an active role (Galusha, 1998). In distance education, students can progress at their own pace; they can check the way they learn, the content, goals and criteria of the subject they learn, and evaluate what they have learned (Kaya, 2002). One of the most critical components of the distance education process is undoubtedly teachers. The teacher is the one who uses and manages the system in virtual classroom education. Although distance education is a process in which the student should take responsibility, it is the teacher's duty to design material for the class, to control and manage the student in this process, and to provide various tools for educational achievements (Aydin, 2017; Yildiz, 2015).

As mentioned earlier, distance education is not a new concept, but COVID-19 has revived the need to explore teaching and learning opportunities online (Almaiah, Al-Khasawneh, \& Althunibat, 2020). Different countries around the world have brought various solutions to continue the education process during the pandemic. Online libraries, TV broadcasts, guides, resources, video lectures, online channels have been promoted in at least 96 countries. For example, in Georgia, the Ministry of Education (MONE), Science, Culture and Sports, launched the educational project "Teleskola" (TV School) in cooperation with the first channel of the Georgian public broadcast to increase the coverage of school classes. The classes across the country were broadcasted live on the TV channel (Basilaia \& Kvavadze, 2020). The Ministry of Education in the Philippines launches the DEPED Commons Project to serve as an online platform for students across the country to participate in virtual classes (Talidong \& Toquero, 2020).

Immediately after the closing of the schools in Turkey on 16th of March in 2020, distance education activities began in a short time as a week. TRT EBA channels were opened on television and internet to access by every child. Extensions were made in this process to ensure equal opportunities. Later on, the EBA 
platform started to be taught synchronously by switching to live classroom applications. It was aimed to make the process efficient by using various instructional materials such as animation and virtual laboratories during the live classes. In addition, the tests solved to measure student performance in the distance education process were systematically followed. However, in the second term of the 2019-2020 academic year, there were no written/oral exams during the semester to be included in the report cards, the first term report card grades were valid in the second term report cards, and they were sent to the students electronically (Ministry of Education, 2020a)

Recently, many studies (e.g. Bakioglu \& Agile, 2020; Cakin \& Kulekci Akyavuz, 2020; Kaden, 2020) have been conducted to determine the effects of the COVID-19 pandemic on education. For example, in a case study examining the changes in the professional life of a secondary school teacher who switched to online education with the closure of their school during the pandemic period in rural America, and the effects on teaching and workload, it is seen that although the workload of the teacher increased, all students, especially poor and disabled students seemed inaccessible to participate in online education (Kaden, 2020). In a phenomenology study on the experiences of science teachers in distance education in Turkey $(n=75)$ were investigated in-depth (Bakioglu \& Agile, 2020). It was found that among the difficulties faced by teachers in distance education during the pandemic, were the problems with an internet connection, inability to communicate with students, the low number of students attending classes and the pressure of the school administration. On the other hand, it was determined that this process has positive effects in terms of using educational technologies and professional development. In another phenomenology study in Turkey, it was found that the primary teachers $(n=20)$, had communication problems in distance education during the COVID-19 period, problems with the parents and issues with students' learning (Cakin \& Kulekci Akyavuz, 2020).

\section{Teacher Self-Efficacy}

The concept of self-efficacy, which we come across in Bandura's Social Learning Theory, is related to the belief in one's own abilities to successfully complete a task assigned to them (Bandura, 1986). Self-efficacy beliefs are effective in determining individuals feelings, thoughts, motivation and behaviour. People with high self-efficacy beliefs behave very decisively in achieving their goals. They can increase their personal satisfaction and success by quickly overcoming the difficulties they encounter as a result of failure or defeat. On the other hand, individuals with low self-efficacy beliefs avoid doing hard work that may cause tension, stress and discontent, they do not make any effort and may give up quickly (Bandura, 1999). Considering these explanations, self-efficacy emerges as an important concept in all areas of life. The teaching profession is one of these areas.

Teachers' self-efficacy beliefs are their judgments about teaching abilities, using teaching strategies, being effective in classroom management, and ensuring student participation (Tschannen-Moran \& Woolfolk Hoy, 2001). Teachers with high self-efficacy are more eager in the learning-teaching process (Tuckman \& Sexton, 1990) and are more successful in classroom management (Gibson \& Dembo, 1984). Teachers' selfefficacy beliefs increase students' motivation to learn and raise their self-perception to a higher level (Midgley, Feldlaufer, \& Eceles, 1989). In addition, there is a high positive relationship between teacher self-efficacy beliefs and student achievement (Allinder, 1995; Ross, 1994). Teachers' self-efficacy beliefs are also related to the choice of method and the time dedicated to teaching. Strong self-efficacy beliefs of teachers directly increase the quality of teaching. In addition, a strong sense of self-efficacy can personally enable the teacher to perform their profession with higher satisfaction and to do it in a healthy way (Cakiroglu \& Isiksal, 2009).

Teachers' self-efficacy beliefs are associated with several factors such as school climate, interpersonal interaction, barriers to effective teaching, teacher empowerment, and school administrators' leadership behaviour (Armstrong-Coppins, 2003; Bandura, 1997; Tschanen-Moran, Woolfolk Hoy \& Hoy, 1998). For example, Hoy and Woolfolk (1993) attributed the increase in teachers' self-efficacy beliefs to the conditions of having high but achievable goals, a serious and orderly learning environment, and academic respect for excellence. School principals undoubtedly have an important role in creating these conditions. It is also important for school principals to appreciate and reward teachers' efforts and achievements (Larrick, 2004). 
Bandura (1997) emphasizes the leadership and empowerment of teachers in strengthening their self-efficacy perceptions, as a matter of fact, teachers who gain leadership and feel the power of authority feel that they are competent in classroom management.

Several empirical studies have been conducted on self-efficacy issue (e.g. Blonder et al., 2013; Lee \& Tsai, 2010). For instance, Compeau and Higgins (1995) found that Canadian managers' and professionals' computer self-efficacy influences their actual computer use. In another study, Lee and Tsai (2010) found that teachers in Taiwan schools, ranging from elementary to high school, lacked technological pedagogical content knowledge related to web but reported high levels of self-efficacy regarding their general use of web. Blonder et al. (2013) showed that a professional development program improved high school chemistry teachers' efficacy beliefs in integrating videos in their chemistry teaching.

The unexpected COVID-19-related disruptions to primary and secondary education created the need to research and document significant changes in teaching practices and teachers' responsibilities (Yang, 2020). Therefore, during the COVID-19 pandemic, it is very important to investigate self-efficacy beliefs of teachers towards distance education. In a qualitative study conducted in Turkey, it was concluded that materials, teaching methods and techniques used by science teachers in their classes changed in this period and they came to the conclusion that they feel inadequate about themselves in distance education (Bakioglu \& Agile, 2020).

\section{Purpose of the Study}

This study aims to determine (i) the level of distance education self-efficacy beliefs of teachers, (ii) factors influencing distance education self-efficacy of teachers, (iii) teachers' opinions about distance education and (iv) the effects of distance education on teachers in Turkey in the process of COVID-19 pandemic. The questions for which answers are sought in the research are as follows:

1. What are the distance education self-efficacy levels of teachers?

2. Do teachers' distance education self-efficacy differ according to the education they received (educational status, whether or not they receive an education on distance education in university and in-service training), the type of school they work in and their active use of technology in their classes before the pandemic period?

3. What are the teachers' views on the efficiency of distance education and live class (the percentage of students attending a live class, the suitability of the class topics to be taught with the live class, the adequacy of the current instructional materials on the platform, the contribution of live class to students' meaningful learning, the comparison of the efficiency of the live class and face-to-face education, whether teaching with live classes is as enjoyable as face-to-face education, the educational success of the current distance education system)?

4. What are the teachers' opinions on the support they receive from the school administration and parents in the distance education process?

5. What are the effects of distance education on teachers (the effect of the number of students attending the live class on their motivation, whether they find the interaction with the computer system annoying, the economic effect of distance education, the effect of their experiences in distance education during the pandemic process on their educational efficiency)?

\section{METHOD}

\section{Research Design}

Survey method was used in the study. The survey method aims to explain individuals' attitudes, opinions, beliefs, demographic characteristics, habits and wishes (Creswell, 2011). In this study, it is used to determine the views on distance education and distance education self-efficacy beliefs of teachers who experienced distance education in Turkey during COVID-19 pandemics period. The study data were collected through an online questionnaire in May and June 2020, and participation in the study was voluntary. 


\section{Participants}

The sample of the study consists of teachers from different branches who actively teach in a public and private school in Turkey, experiencing the distance education during the COVID-19 pandemic in the spring semester of 2019-2020 academic year. In the study, a total of 758 teachers from 55 different provinces of Turkey and from 24 different branches participated. Participants' experience in the profession is average of $9.83(\mathrm{SD}=7.24)$ years. The majority of the teachers $(85.4 \%)$ stated that they did not receive any training in distance education in university life, and $14.6 \%$ of them stated that they received training on this subject. Similarly, teachers who do not receive in-service training on distance education dominate; $78.5 \%$ of them did not receive in-service training on this subject, and $21.5 \%$ of them did. Other demographic information of the sample is presented in Table 1.

Table 1. Demographic information of the sample

\begin{tabular}{|c|c|c|c|}
\hline & & Frequency & $\%$ \\
\hline \multirow[t]{3}{*}{ Gender } & Female & 570 & 75.6 \\
\hline & Male & 184 & 24.4 \\
\hline & Missing & 4 & 0.5 \\
\hline \multirow[t]{4}{*}{ Faculty graduated in the university } & Faculty of Education & 592 & 78.1 \\
\hline & Faculty of Arts and Sciences & 105 & 13.9 \\
\hline & Faculty of Engineering & 12 & 1.6 \\
\hline & Other & 49 & 6.5 \\
\hline \multirow[t]{3}{*}{ Educational status } & Bachelor's degree & 631 & 83.2 \\
\hline & Post-graduate & 113 & 14.9 \\
\hline & Doctor's degree & 14 & 1.8 \\
\hline \multirow[t]{2}{*}{ Type of school } & Public school & 713 & 94.1 \\
\hline & Private school & 45 & 5.9 \\
\hline \multirow[t]{4}{*}{ Settlement of the school } & City center & 392 & 51.7 \\
\hline & District & 225 & 29.7 \\
\hline & Town & 11 & 1.5 \\
\hline & Village & 130 & 17.2 \\
\hline
\end{tabular}

\section{Data Collection Tools}

As a data collection tool, an online questionnaire form consisting of three parts was used. In the first part of the questionnaire, there were questions about gender, faculty from which they graduated, educational status, type of school, settlement of the school, whether they have received any education on distance education in university life and in-service education to determine the demographic characteristics of teachers.

In the second part of the questionnaire, a unidimensional scale developed by Yildiz (2015) to determine the self-efficacy perceptions of instructors towards distance education was used to determine the distance education self-efficacy of teachers. Since the scale was developed for teaching staff, confirmatory factor analysis was performed using the LISREL 8.8 program (Joreskog \& Sorbom, 2007) to test its suitability to the sample group consisting of teachers. The goodness of fit indices obtained from the analysis showed that the data set fit well with the proposed structure $(S-R M R=.056$, NNFI $=.932$, CFI $=.947$, IFI $=.947)$. There are ten items in the scale and are answered in a 5-point Likert type $(1=$ not sufficient at all, $5=$ very sufficient). The scale requires the participants to evaluate the ability to use tools such as computers and cameras required by the distance education system, to use components such as forums and messages, to integrate 
the technologies they deem necessary into their class, to solve the problems they encounter, to organize various instructional materials and teaching activities for effective class environments, to prepare different assessment and evaluation activities and their belief in their abilities to provide classroom management in virtual classrooms. In this study, the Cronbach alpha coefficient of the reliability of the scores obtained in the scale items was .95.

In the third part of the questionnaire, 18 closed-ended questions, mostly with yes/no options, and an openended question that allows teachers to express their opinions about their distance education experiences were used. The questions in this section were developed by the researchers and are given in the Appendix. The relevance of the items in terms of content was examined by two faculty members. One of the faculties was from department of computer and instructional technologies education and the other was from department of mathematics and science education. In order to evaluate the items in terms of spelling and clarity, the opinions of three Turkish teachers were consulted. The items were arranged according to the feedback received. The questionnaire was delivered to 30 teachers via e-mail for pilot application. In general, there was no problem in the pilot implementation, some changes were made in some items, and the final version of the questionnaire was decided.

\section{Data Analysis}

The SPPS 23 program was used in the analysis of the data obtained from the closed-ended questions and scale items of the questionnaire. Descriptive statistics were used to determine teachers' distance education self-efficacy levels (research question 1), teachers' views on distance education and the efficiency of live class (research question 3), teachers' opinions about the support they receive from school administration and parents in the distance education process (research question 4), and the effects of distance education on teachers (research question 5).

Five separate independent samples t-tests were conducted to evaluate whether the distance education selfefficacy of teachers differentiates according to their education (educational level, whether they received an education about distance education in university life and in-service education), the type of school they work in and their active use of technology in their classes before the pandemic period (research question 2). The results were evaluated using Bonferroni adjustment to reduce the possibility of falling into type- 1 error.

Content analysis was used in the analysis of the answers given to the open-ended question in the questionnaire. Two of the authors of the study examined participants' responses and formed codes and categories individually. Later, these researchers came together to see if there was a consistency between codes and categories. It was observed that there was consistency in most of the analysis, and the points where there were differences were discussed and agreed upon, that is full agreement was reached. Then another author of the study examined the analysis, and the codes and categories were finalized.

\section{FINDINGS}

\section{Distance Education Self-Efficacy of Teachers}

When the responses of teachers who teach distance education during the pandemic to the distance education self-efficacy scale $(M=3.61, S S=.68)$ are examined, teachers believe that that they are partially sufficient or sufficient to use the tools required by the distance education system such as a computer, camera, sound system, and use system components such as forums and messages; to be able to integrate the technologies they deem necessary into their class, to be able to manage the classroom in virtual classrooms and solve the problems they encounter in the distance education system, to organize effective course environments, to prepare various instructional materials, and to prepare different assessment and evaluation activities. Teachers' responses to the questionnaire items also support this result. More than half of the participants (52.0\%) think that they cannot easily create a classroom environment and teach in any situation through the live class. The rate of teachers who think that they cannot perform assessment and evaluation effectively in distance education is $73.1 \%$. These results show that teachers' belief in their own abilities in fulfilling the requirements of distance education is not at a high level. 


\section{The Effects of Active Use of Education, School Type and Technology on Distance Education Self-Efficacy of Teachers}

Five independent samples t-test were conducted to determine whether the distance education self-efficacy of teachers differentiates according to their education (educational status, university life and whether or not they received an education on distance education in in-service training), the type of school they work in, and their active use of technology in their classes before the pandemic period. By using Bonferonni adjustment $(.05 / 5)$, the results were evaluated with an alpha value of .01 (See Table 2).

According to the results, teachers who have a post-graduate education degree have higher self-efficacy than teachers who have graduated from undergraduate education, teachers who received a distance education training in the university have higher self-efficacy than teachers who did not receive a distance education training in university, and teachers who received a distance education training in in-service education have higher self-efficacy than teachers who did not receive a distance education training in in-service education. This situation supports that the education teachers receive has positive effects on their distance education self-efficacy.

When the distance education self-efficacy of teachers is compared according to the type of school they work in, it is seen that teachers working in private schools have higher levels of self-efficacy than teachers working in public schools. Teachers who actively use technology in their classes before the pandemic period also have higher self-efficacy beliefs in distance education than teachers who do not use it. The calculated eta square effect size values are small according to Cohen (1988)'s criteria.

Table 2. Comparison of teachers' self-efficacy towards distance education according to the education they received, the type of school they work in and active use of technology before the pandemic period

\begin{tabular}{|c|c|c|c|c|c|c|c|}
\hline Group & $\mathbf{N}$ & M & SD & $\mathbf{t}$ & df & $\mathbf{p}$ & $\begin{array}{c}\text { Eta } \\
\text { square }\end{array}$ \\
\hline Having a bachelor's degree & 631 & 3.57 & 68 & \multirow{3}{*}{-4.04} & \multirow{3}{*}{756} & \multirow{3}{*}{.00} & \multirow{3}{*}{.02} \\
\hline & & & & & & & \\
\hline Having a post-graduate education degree & 127 & 3.84 & .67 & & & & \\
\hline Receiving distance education training in university & 111 & 3.91 & .62 & \multirow[b]{2}{*}{5.05} & \multirow[b]{2}{*}{756} & \multirow[b]{2}{*}{.00} & \multirow[b]{2}{*}{.03} \\
\hline $\begin{array}{l}\text { Not receiving any distance education training in } \\
\text { university }\end{array}$ & 647 & 3.56 & .68 & & & & \\
\hline $\begin{array}{l}\text { Receiving distance education training in in-service } \\
\text { training }\end{array}$ & 163 & 3.89 & .63 & \multirow[b]{2}{*}{5.96} & \multirow[b]{2}{*}{756} & \multirow[b]{2}{*}{.00} & \multirow[b]{2}{*}{.04} \\
\hline $\begin{array}{l}\text { Not receiving any distance education training in in- } \\
\text { service training }\end{array}$ & 595 & 3.54 & .68 & & & & \\
\hline Working in a public school & 713 & 3.59 & .69 & \multirow[b]{2}{*}{-4.74} & \multirow[b]{2}{*}{54.17} & \multirow[b]{2}{*}{.00} & \multirow[b]{2}{*}{.03} \\
\hline Working in a private school & 45 & 3.98 & .52 & & & & \\
\hline $\begin{array}{l}\text { Actively using technology in their classes before the } \\
\text { pandemic }\end{array}$ & 590 & 3.69 & .66 & \multirow{2}{*}{5.72} & \multirow{2}{*}{756} & \multirow{2}{*}{.00} & \multirow{2}{*}{.04} \\
\hline $\begin{array}{l}\text { Not actively using technology in their classes before } \\
\text { the pandemic }\end{array}$ & 168 & 3.35 & .68 & & & & \\
\hline
\end{tabular}




\section{Teachers' Views on the Efficiency of Distance Education and Live Classes}

More than half of the teachers (59.5\%) stated that the class size of the students attending the live class was between 1\% and 25\% (see Figure 1). The rate of teachers (5.67\%) who stated that more than $75 \%$ of the students in their classes attend the live class was quite low. All of the participants stated that the number of students attending the live class was low. According to the teachers, the most suitable time for the live class was 11:00-13:00 (37.9\%), 13:00-15:00 (30.1\%) and 9:00-11:00 (20.3\%).

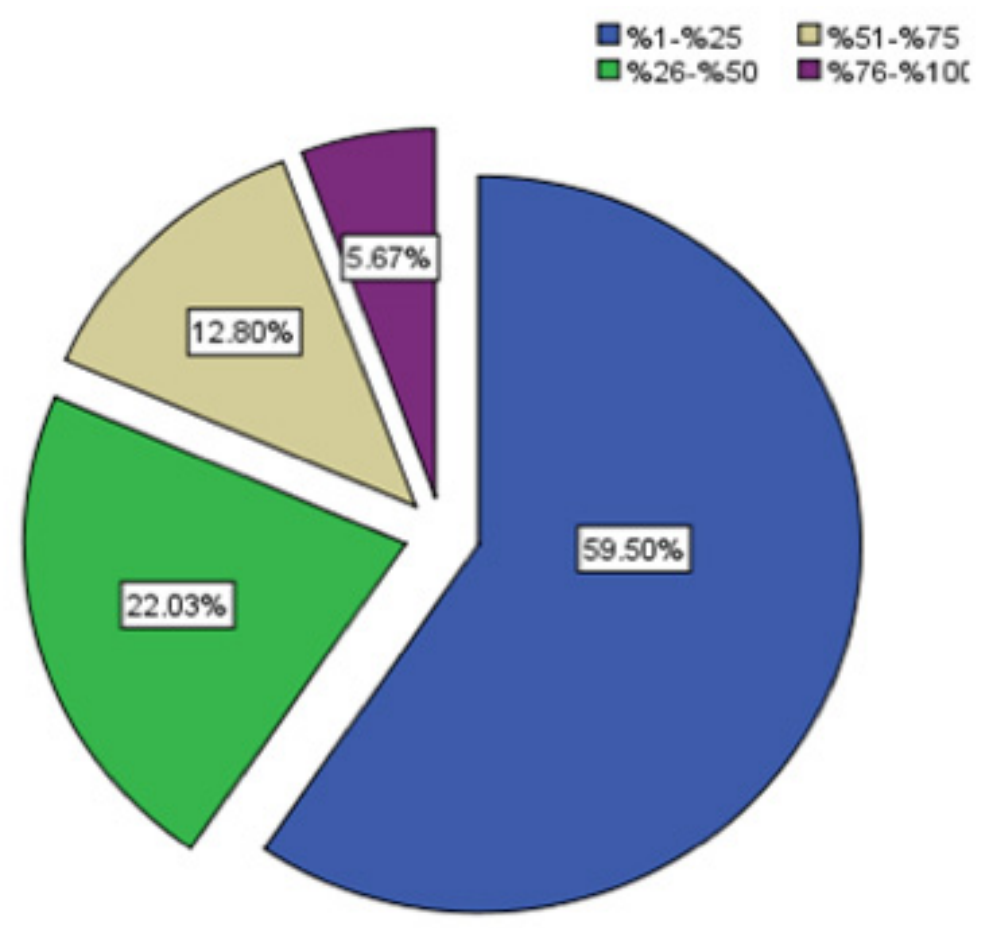

Figure 1. The proportion of students attending the live course

Approximately half of the participants found the course subjects suitable for teaching with live classes, while the other half did not find it appropriate. Majority of the teachers $(79.02 \%)$ did find the current instructional materials on the platform sufficient in order for the students to be successful. On the other hand, $41.69 \%$ of the teachers thought that live classes contributed to students' meaningful learning, while $58.31 \%$ did not agree with this. While only $6.46 \%$ of the teachers thought that the classes taught through live classes were as efficient as face-to-face education, the vast majority $(93.54 \%)$ disagreed with this. The rate of teachers who found teaching with live classes more enjoyable than teaching with face to face was quite low $(8.18 \%)$. Nearly half of the teachers $(44.46 \%)$ found the current distance education system educationally successful, while $55.54 \%$ did not find it successful (See Table 3).

Table 3. Teachers' opinions about the efficiency of distance education

\begin{tabular}{lcc}
\hline & Yes (\%) & No (\%) \\
\hline The suitability of the class subjects to teach with live class & 49.47 & 50.53 \\
Sufficiency of the instructional materials available on the platform & 20.98 & 79.02 \\
Live classes contributing to students' meaningful learning & 41.69 & 58.31 \\
Live classes are as efficient as face-to-face education & 6.46 & 93.54 \\
Finding the teaching of live classes more enjoyable than face-to-face education & 8.18 & 91.82 \\
Finding the current distance education system educationally successful & 44.46 & 55.54 \\
\hline
\end{tabular}




\section{Teachers' Opinions about the Support They Receive From the School Administration and Parents}

Teachers were asked about the support they received from the school administration and parents during distance education. About three-quarters of the teachers stated that they received sufficient support from the school administration in the distance education process, while rest of them did not. Slightly more than half of the teachers received support from their institution to solve the technical problems they encounter in live classes. One fourth of the teachers stated that they received sufficient support from parents in the distance education process, while the vast majority reported that they did not receive sufficient support from parents in this process (See Table 4).

Table 4. Teachers' opinions about the support they receive during distance education

\begin{tabular}{lcc}
\hline & Yes (\%) & No (\%) \\
\hline $\begin{array}{l}\text { Receiving sufficient support from the school administration in the distance } \\
\text { education process }\end{array}$ & 71.14 & 25.86 \\
$\begin{array}{l}\text { Receiving support from the institution for technical problems faced during live } \\
\text { classes }\end{array}$ & 55.41 & 44.59 \\
Receiving sufficient support from parents in the distance education process & 25.20 & 74.80 \\
\hline
\end{tabular}

\section{Effects of Distance Education on Teachers' Motivation, Economic Situation and Efficiency in Education}

Effects of distance education on teachers were also focused. $80.21 \%$ of the teachers stated that the fact that the number of students attending live classes is less than the class size negatively affects their motivation as a teacher. Besides, $42.74 \%$ of the teachers find the interaction with the computer system annoying. When examining the economic impact of distance education on teachers, one-fourth of the teachers $(25.20 \%)$ reported that distance education imposed an economic burden on them. On the other hand, the rate of teachers $(69.39 \%)$ who thought that their experiences in distance education during the pandemic increased their efficiency in education was high (See Table 5).

Table 5. Effects of distance education on teachers

\begin{tabular}{lcc}
\hline & Yes (\%) & No (\%) \\
\hline Negative effects of the few student participation in the live classes on their motivation & 80.21 & 19.79 \\
Finding interaction with the computer system annoying & 42.74 & 57.26 \\
Economic burden of distance education & 52.20 & 74.80 \\
Increasing the efficiency of their experiences in distance education & 69.39 & 30.61 \\
\hline
\end{tabular}

In the last question of the questionnaire, an open-ended question that reads "please write if there is anything else you want to add about your distance education experiences" was asked to the teachers and 198 teachers answered this question. Content analysis was performed on the answers given, and codes and categories were created (Table 6). 
Table 6. Teachers' opinions on their distance education experiences

\begin{tabular}{|c|c|c|}
\hline Category & Code & Frequency \\
\hline \multirow{6}{*}{$\begin{array}{l}\text { System errors and } \\
\text { infrastructure problem }\end{array}$} & Students not having a computer and/or internet & 42 \\
\hline & Systemic errors (system dismissals, interruption of classes, etc.) & 25 \\
\hline & Lack of infrastructure & 10 \\
\hline & Internet infrastructure problem & 3 \\
\hline & Inadequate internet quota & 3 \\
\hline & Teachers not having a computer and/or internet & 3 \\
\hline \multirow{4}{*}{$\begin{array}{l}\text { The efficiency of distance } \\
\text { education }\end{array}$} & Not as efficient as face-to-face training & 42 \\
\hline & Not being effective alone & 5 \\
\hline & Not suitable for younger students & 3 \\
\hline & Not suitable for special education students & 1 \\
\hline \multirow{4}{*}{$\begin{array}{l}\text { Inequality of opportunity } \\
\text { in education }\end{array}$} & Causes inequality of opportunity in education & 23 \\
\hline & Inequality of opportunity for students with no financial means & 13 \\
\hline & Inequality of opportunity for students in rural areas & 11 \\
\hline & Not all students can benefit & 2 \\
\hline \multirow{6}{*}{$\begin{array}{l}\text { Problems caused by } \\
\text { school administration and } \\
\text { MEB }\end{array}$} & Teachers' course load, working hours and responsibilities increase & 10 \\
\hline & Weak EBA course content/lack of documentation & 4 \\
\hline & School management not supporting teachers & 3 \\
\hline & Pressure implemented by the school management & 2 \\
\hline & Ignoring the suitability of class hours to the teacher & 1 \\
\hline & Institutions not taking part in the preparation of class slides & 1 \\
\hline \multirow{2}{*}{$\begin{array}{l}\text { Problems with student } \\
\text { attendance and } \\
\text { motivation }\end{array}$} & Low student participation & 18 \\
\hline & Low student motivation & 2 \\
\hline \multirow{4}{*}{ Teacher-related problems } & $\begin{array}{l}\text { Teachers' lack of knowledge and experience in distance } \\
\text { education/need for in-service training on distance education }\end{array}$ & 9 \\
\hline & Teachers are not familiar with technology & 4 \\
\hline & Low teacher motivation & 3 \\
\hline & Indifference and irresponsibility of teachers & 2 \\
\hline \multirow{7}{*}{$\begin{array}{l}\text { Problems with the live } \\
\text { class }\end{array}$} & No obligation to attend & 6 \\
\hline & Difficulty teaching math classes & 3 \\
\hline & Turned-off student cameras & 3 \\
\hline & Limited assessment and evaluation & 2 \\
\hline & Difficulties in classroom management & 2 \\
\hline & Not staying in classes & 1 \\
\hline & Short class time & 1 \\
\hline
\end{tabular}




\begin{tabular}{|c|c|c|}
\hline & Parents' lack of interest & 9 \\
\hline \multirow[t]{4}{*}{ Parent-related problems } & Parents not knowing about distance education & 3 \\
\hline & Parents intervening too much & 1 \\
\hline & Increasing teachers' experience about distance education & 5 \\
\hline & Students stay in the education process & 4 \\
\hline \multirow[t]{3}{*}{$\begin{array}{l}\text { Positive aspects of } \\
\text { distance education }\end{array}$} & Can be used as support when returning to face-to-face education & 2 \\
\hline & Students gain experience in distance education & 1 \\
\hline & Giving a different perspective on education & 1 \\
\hline
\end{tabular}

It was observed that teachers primarily drew attention to the systemic mistakes and infrastructure problems they experienced in distance education. The main problems were students' lack of computers and/or internet $(\mathrm{f}=42)$, systemic errors $(\mathrm{f}=25)$ such as the dismissal of the system and interruption of courses, and lack of infrastructure $(\mathrm{f}=10)$. The opinion of a teacher on this subject is as follows:

Logins to the system are not easy. According to the information we obtained from the students, there were those who could not try to log into the system for hours. The infrastructure needs to be improved. The system can kick us during the class, and sometimes we can't even enter the class. Students do not attend the class; they do not do the given homework. The system constantly ranks teachers according to the time, but there is no activity in the system which we can spend 5-6 hours on.

Referring to the issue of the efficiency of distance education, teachers think that distance education is not as efficient as face-to-face education. One of the participants expressed their opinion on this issue as follows: "Even the best distance education cannot be as beneficial as face-to-face education." (T:714)

Teachers reported that distance education application causes inequality of opportunity in education. Teachers stated that it mainly causes inequality of opportunity in education $(\mathrm{f}=23)$, there is no equality of opportunity for students who do not have financial means $(\mathrm{f}=13)$ and students in rural areas $(\mathrm{f}=11)$. One of the teachers expressed their opinion on this issue as follows: "Since most of my students come from the village, we had great difficulties and injustice in education emerged. Great gaps were created between the student having all the opportunities in the city center and the village students. This situation has worn us and our students psychologically" (T:491). Another teacher wrote:

Some students must have the necessary technological equipment to benefit from this process (phone, tablet, PC, internet, etc.). However, unfortunately, students living in rural areas could not benefit from the distance education process effectively because they were deprived of these equipment. (T:736)

In the distance education process, it was observed that teachers had problems related to school administration and MONE. Teachers stated that the distance education process was tiring for them due to the increase in their responsibilities such as the increase in the course load and working hours and the need to communicate with parents, administration and students continuously $(\mathrm{f}=10)$. Lack of EBA course content/lack of documents $(\mathrm{f}=4)$ and the school administration's lack of support for teachers $(\mathrm{f}=3)$ are among the other problems they experienced. The statements of some teachers regarding this subject are as follows: "It is a very tiring and difficult process" (T:13). "I believe that the school administration has worn down teachers in this process, instead of increasing teacher motivation, some sanctions that stress teachers are applied, and this needs to be resolved." (T:236)

It is observed that there are problems with student participation and motivation in distance education. One of the teachers, who stated that student participation was low $(\mathrm{f}=18)$, added "The biggest problem is low participation" (T:193). Another teacher expressed their views as follows:

Unfortunately, as a teacher working in village conditions, I can say that it is not a system that every student can benefit from. We have students who live in many villages, but they do not have internet infrastructure in their villages, their phones do not have any reception, they do not have computers, and they can only 
participate in the class if their parents are at home. The number of students who can attend a class does not exceed 3 out of 35 people. We are constantly experiencing disconnections; in such a case, it is not possible to talk about the efficiency of the course. Under the conditions, this is the best of a bad lot, but as I said, some improvements must be made for a system that every student can benefit from. (T:231)

When the answers of the participants are examined, it is seen that there are also problems with the teacher. Teachers 'lack of knowledge and experience in distance education/ their need in in-service training on distance education $(f=9)$ and the fact that they are unfamiliar with the technology $(f=4)$ are among the main problems mentioned. While one teacher said, "we would have been more efficient if we had received his education beforehand" (T:284), another teacher expressed their thoughts as follows:

During the distance education process, a compulsory seminar should be given to each teacher on subjects such as creating live course material and using material during the live class. Each teacher strives to learn something in this process with his own efforts, and unfortunately, most of the information we learn is hearsay. We all need more professional help in this regard. (T:307)

It is observed that teachers also have problems with live classes. Some teachers emphasize that attendance should be mandatory $(\mathrm{f}=6)$. A teacher wrote the following on the subject: "I think it will be a successful system provided that attendance is mandatory when students have sufficient equipment for distance education." (T:726)

Mentioning that problems with parents were also experienced during the distance education process, teachers pointed out that parents were indifferent $(f=9)$ and ignorant about distance education $(f=3)$. The statements of two of the teachers who voiced this issue are as follows: "It is a big problem that parents have trouble about the internet and cannot fully control the subject" (T:73). "Too many parents who do not adapt to technology, the indifference of parents" (T:500).

There were also participants who stated that distance education has positive aspects. The main positive effects are the increase in teachers 'experience about distance education $(\mathrm{f}=5)$ and the fact that students continue to stay in the education process $(\mathrm{f}=4)$. Two teachers expressed their views on this issue with the following sentences: "... I think it is a process that breaks prejudices and gives us all the familiarity with the educational use of technology. In this respect, it is a nice experience" (T:551). "Having distance education during the pandemic period has been very good for children not to break away from education. However, no technology can replace face-to-face education" (T:609). In general, it was observed that the teachers' responses to the open-ended question of the questionnaire coincided with their answers to the closed-ended items.

\section{DISCUSSION AND CONCLUSION}

In this study, (i) the AND level of distance education self-efficacy beliefs of teachers who switched to distance education, (ii) factors affecting distance education self-efficacy beliefs, (iii) teachers' views on distance education and (iv) the effects of distance education on teachers in Turkey during the COVID-19 pandemic were examined. In the first question of the study, the distance education self-efficacy levels of the teachers were discussed. In distance education, it has been observed that teachers' beliefs in their own abilities are not at a high level in fulfilling the requirements of distance education such as organizing effective class environments in the system, solving the problems they encounter, preparing different assessment and evaluation activities. Similar findings in other studies conducted in Turkey have been obtained. It has been found that science teachers who provided distance education during the COVID-19 period had problems with software/hardware, internet connection, computer programs, computer accents and not knowing how to use the computer (Bakioglu \& Cevik, 2020). According to the report published by UNESCO (2020a), during the COVID-19 period, teachers had to be quickly involved in the distance education process without taking their ideas and providing the necessary training and faced with pressures to use distance education methods and tools. In the report, it was emphasized that teachers should be informed and supported on these issues. As a matter of fact, in a study conducted in Slovenia at the beginning of COVID-19, it was found that teachers with higher self-efficacy in information and communication technologies have more positive attitudes towards distance education (Košir et al., 2020). These results show that teachers' distance education self-efficacy should be supported. 
In the second question of the study, the factors affecting the distance education self-efficacy beliefs of teachers were examined. According to the teachers who have a post-graduate education degree; It was observed that teachers who received a distance education training in university had higher self-efficacy than teachers who did not, and teachers who received training on distance education in in-service training had higher selfefficacy than teachers who did not. This shows that the education teachers receive has positive effects on their distance education self-efficacy. However, it was determined that the majority of teachers (85.4\%) who did not receive any training in distance education during university and did not attend in-service training (78.5\%) on this subject. In the answers they gave to the open-ended question of the questionnaire, there were teachers who stated that they did not have knowledge and experience in distance education and that they needed in-service training on this subject. In her study, Iwai (2020) reported that with the sudden transition to platforms used in distance education in the COVID-19 pandemic, especially educators who are less equipped on the internet and computers, have difficulty in managing virtual classes mediated by a screen and microphone. These results indicate that it is important to support teachers by improving their knowledge and skills in distance education through trainings to strengthen their self-efficacy in distance education.

In the study, it was determined that teachers who actively used technology in their classes before the pandemic period had higher self-efficacy beliefs in distance education than teachers who did not use it. When the distance education self-efficacy of the participants was compared according to the type of school they worked, it was found that teachers working in private schools had higher levels of self-efficacy than teachers working in public schools. The reason for this may be that private school teachers are more accustomed to using technology in their teaching, as the technological facilities of private schools are better than public schools. Another reason may be that the support provided by the school administration and parents to teachers for distance education in private schools is better than in public schools. In her article on this subject, Winter (2020) shared an article in which a teacher working at a private school in Italy during the COVID-19 process wrote about his experiences during this process. This teacher stated that all children have tablets in the school where she works and that the students studying at the public school are educated through written documents prepared by the teachers and delivered to their parents.

In the third question of the study, teachers' opinions about the efficiency of distance education and live classes were analyzed. All of the teachers stated that the number of students attending live classes was low. Similarly, in the analysis of the responses of the teachers to the open-ended questionnaire item, it was found that student participation and student motivation were low in the distance education process. Similarly, it has been demonstrated in other studies conducted during the pandemic period that students' participation in online or offline classes is low (e.g. Bakioglu \& Cevik, 2020). Among the reasons for the low participation of students in live classes, there may be reasons such as the lack of internet infrastructure in the student's residential area, lack of equipment due to economic reasons, the lack of interest of parents, the disappearance of the class not passing by the Ministry of Education, and the thought that the efficiency of face-to-face education cannot be obtained in distance education. As a matter of fact, in the responses of teachers to the open-ended questionnaire, students' lack of computers and/or internet and systemic errors (dismissing the system from the course, interruption of the classes etc.) are among the most common problems. In addition, some teachers stated that distance education causes inequality of opportunity for students in rural areas and without financial means.

In other studies, the fact that the system infrastructure is not sufficient, not every student has educational materials such as computers and tablets (Basaran, Dogan, Karaoglu, \& Sahin, 2020) and all students, especially poor and disabled students, cannot be reached to participate in online education (Kaden , 2020) have emerged as situations that complicate and negatively affect the process. In this study, again, according to the answers given by the teachers to the open-ended questionnaire item, the absence of attendance obligation causes students to have less participation in live lessons.

According to the findings obtained in the study, half of the teachers stated that subjects were suitable for teaching through live classes, while the other half stated that it was not. According to the responses of the teachers to the open-ended questionnaire, some teachers think that it is difficult to teach math classes in the live classes. This situation may be caused by factors such as the content of the course and the teacher's computer literacy. While lessons with verbal content such as Turkish, Social Studies, History can be taught 
more easily in the distance education process, it can be difficult to teach classes that require practice such as Science, Physics, Chemistry, due to the lack of time, space and material limitations. At the same time, it can be thought that teachers who are qualified to use information technology find their classes suitable for teaching with live classes. As a matter of fact, Ustun, Karaoglan Yilmaz and Yilmaz (2020) emphasized the importance of improving teachers' self-efficacy in using information and communication technologies for their success in distance education environments.

According to another result reached in this study, most of the teachers $(79.02 \%)$ do not find the current instructional materials on the platform sufficient for the students who receive distance education to be successful. In their response to the open-ended question in the questionnaire, the teachers also stated that the EBA class content was poor, and they lacked documents. In a previous study, the effects of the Education Informatics Network (EBA) application, which is the official digital education platform of the Ministry of Education in social studies teaching, on the achievements of the students were examined, and it was concluded that EBA should be developed as content (Yerli, 2018). EBA has been inadequate in terms of content, although some innovations have been made due to the rapid transition to the distance education process due to the COVID-19 pandemic. Similar results have been demonstrated in other studies. For example, Yilmaz (2020) stated in his study that he made suggestions for the improvement of distance education that the instructional materials in EBA are not at a sufficient level in terms of using them in distance education. Cakin and Kulekci Akyavuz (2020), in their study to determine the problems experienced by teachers in distance education, concluded that the lack of material reduces the efficiency of the classes and limits the activities to be performed. Ertan Kantos (2020) also emphasized that the content of EBA should be increased on the basis of class, as a result of the interviews with primary school teachers in order to learn their opinions about distance education. According to Bakioglu and Cevik (2020), it was stated that there were problems related to conducting the laboratory or workshop studies included in the science classes during the distance education process, and that these problems were tried to be eliminated by sending various experiment videos to eliminate these problems or by asking students to conduct individual experiments at home. These results indicate that the class contents of EBA should be improved.

According to the results obtained in this study, the rate of teachers who think that the classes taught with live classes are as efficient as the face-to-face education (6.46\%) and who find it more enjoyable to teach with live classes than face-to-face education is quite low (8.18\%). Similarly, in their responses to the open-ended questionnaire, it was observed that the teachers had the opinion that distance education was not as effective and efficient as face-to-face education. Teachers who are used to face-to-face education have faced a number of difficulties in the distance education process they have gone through with the COVID-19 pandemic.

Internet connection problems, insufficient ability to use technology, teachers' lack of control over the class and student, their inability to communicate with the student properly, student reluctance, and parents' indifference were among these difficulties. In a study examining the opinions of classroom teachers about distance education, it was found that all participants preferred face-to-face education, and the hybrid education system can be used in compulsory situations (Ertan Kantos, 2020). Similarly, another study has shown that teachers working in primary education during the COVID-19 process think that distance education is not as effective as face-to-face education (Cakin \& Kulekci Akyavuz, 2020).

More than half of the teachers participating in this study stated that live classes did not contribute to students' meaningful learning and that they did not find the existing distance education system educationally successful. The fact that the number of students attending live classes is low and that they find the materials on the existing platforms inadequate may be effective in their thinking. In addition, considering that education is a multi-dimensional behavioral change, educational activities in the current distance education process are mostly limited in the form of knowledge transfer. Similarly, Yilmaz (2020) stated that the current situation expressed as distance education is not distance education but a distance education or learning.

In the fourth question of the study, the opinions of the teachers about the support they received from the school administration and parents were analyzed. Most of the teachers who participated in the study stated that they received support from the school administration, and a quarter did not. Nearly half of the participants did not receive support from their institution to solve technical problems they encounter in the live class. The responses given to the open-ended questionnaire also supported these findings. Some teachers 
stated that the school administration did not support them and their course load, working hours and responsibilities increased during the distance education period. Compared to the situation where face-toface education is carried out, it was seen that teachers are faced with a much more intense workload, demand and expectation due to the easy accessibility of communication technologies in the virtual environment. It is important to support teachers who make a rapid transition to the distance education process in this regard. UNESCO (2020b) emphasizes that the critical roles of teachers should be recognized and supported in order to overcome the COVID-19 pandemic more easily and in a shorter time. Since they have an active role in ensuring the continuity of teaching, teachers have to be informed and supported in these and similar situations, but without the teachers' ideas and providing them with sufficient opportunities, teachers have faced pressures on some distance education methods and technologies (Saklan \& Unal, 2019). These results reveal that the administrations of schools that do not support their teachers should try to meet their teachers' needs more.

The majority of the teachers who participated in the study (74.80\%) stated that they did not receive support from parents in this process. Similarly, in the responses given to the open-ended questionnaire, there were teachers who mentioned that parents were indifferent and uninformed about distance education. In this process, it was determined in other studies that parents were indifferent and did not keep an eye on the students while they were on the computer (Basaran et al., 2020; Bayburtlu, 2020). However, the fact that parents are indifferent and not mediating in communication with the teacher negatively affects the relationship of the students with the school (Cakin \& Kulekci Akyavuz, 2020). Therefore, parent-teacher relationship is very important for an effective learning process (Calik, 2007). The parent-teacher relationship should be handled with importance in the distance education process as in all processes of the school (Murray, 2009). Therefore, parents not having enough support can be an important factor in not getting enough efficiency in distance education.

In the last question of the study, the effects of distance education on teachers were discussed. The majority of the teachers $(80.21 \%)$ stated that less than the class size of the students attending the live lesson negatively affected their motivation as a teacher. Teachers who are used to face-to-face education with their students can be expected to be negatively affected by the low participation of their students in live classes. In their study, Bakioglu and Cevik (2020) revealed that their students might lack knowledge, feel inadequate in the distance education process, and teachers are anxious during this process because they cannot communicate with the student. Some of the teachers participating in the research find the interaction with the computer annoying. Long course hours and increased workloads may have caused this situation. In addition, teachers' lack of computer interactions and difficulties in overcoming technical problems may have led to this situation. As a matter of fact, the problems of teachers about using technology in the distance education process are an important issue, because teachers who need to have basic computer knowledge in order to use digital teaching materials have various problems. Even a process that can be handled in a very short time when sufficient information is not available takes teachers' hours and thus causes a waste of time (Saklan \& Unal, 2019). When the findings of the economic impact of distance education on teachers were examined, some of the teachers who had live classes stated that their burden increased economically. In this process, the need for computers, the need to expand their internet quotas, and the efforts of those living in disadvantaged areas to access internet connection can have economic effects on teachers.

It was determined that the transition to distance education has positive effects as well as negative effects on teachers. Most of the participants (69.39\%) think that their experiences in distance education during the pandemic process increase their efficiency in education. Similarly, in their responses to the open-ended item, the teachers mentioned that one of the positive reflections of this process was that their experiences about distance education increased. In addition, they stated that there are positive aspects of distance education, such as keeping students in the education process and distance education being used as support when returning to normal education. During the pandemic period, teachers had to make a very rapid transition to distance education and tried to adapt to the situation in a short time. However, it is an important finding that most of the teachers stated that their experiences in this process increased their efficiency in teaching. The fact that teachers and students, who are a one-to-one interaction in the classroom environment, start teaching lessons in virtual classrooms has made it compulsory for teachers to use various technologies. This obligation may have led teachers to use educational technologies more effectively. In order to make teaching 
effective and to increase the quality of education, it became necessary to use various teaching materials such as videos and slides more actively, and therefore teachers had to be prepared more comprehensively in terms of content. These situations may have affected teachers' productivity positively. Similarly, Bakioglu and Cekik (2020) found that the pandemic process had positive effects on teachers in terms of using educational technologies and professional development. In this process, some resources have been created to guide teachers. For example, UNESCO (2020b) has prepared a guide on technologies for teachers to use during the pandemic. MONE has also created various informative videos for teachers, students and parents during the distance education process (Ministry of Education, 2020b). Resources like these may have helped teachers improve themselves during the pandemic process.

\section{Suggestions and Limitations}

In line with the results obtained in the study, the following suggestions can be made for using the distance education system more effectively:

In order to achieve the desired efficiency in the distance education system where information technology is used, first of all, internet infrastructure problems should be solved and fast and cheap internet access should be provided,

In order to increase the participation rate of students in live lessons and to ensure equality of opportunity in education, the Ministry of Education should identify the students in need and provide them with the necessary equipment (device supply, internet connection) for distance education,

Face-to-face education should be used in settlements where internet infrastructure is insufficient and the number of students is low, and where distance education cannot be performed (this should also apply to students with special education needs) by taking necessary precautions in terms of health,

The infrastructure of EBA, which is the official digital education platform of the MONE, should be empowered to make it suitable for the simultaneous use of all students, the EBA course contents should be enriched in a way to include each course and the acquisition evaluation tests should be increased,

In order to get the desired level of efficiency from the distance education process, all teachers should be provided with in-service training on distance education. In-service training can introduce teachers with technologies used in distance education and enable teachers' practice these technologies in order to increase teachers' familiarity and efficient use of these technologies and improve their knowledge and pedagogical skills in distance education. This training should be repeated at certain intervals considering the change in information technologies, teachers' needs and their working conditions,

Students and parents should be educated about the platforms that can be used in live classes in distance education, and parents should be informed about how they can better support their children in this process,

The necessary equipment (camera, sound system, computer, etc.) should be provided for distance education to each teacher by the MONE or economic support should be provided for this,

A team in each school should be established to solve technical problems that may be experienced in live lessons, working in cooperation with teachers and parents should work in cooperation with the team and quickly eliminate the problems experienced,

Teachers should use their experiences about distance education during the pandemic period together with face-to-face education (they should provide distance education to students who cannot attend school for a long time or who have low achievement due to illness, family problems, etc.),

To increase the number of students attending live classes; obligatory attendance, providing parent support, enriching the course contents, increasing the interaction of students with each other and using teaching techniques suitable for distance education may be beneficial.

This study has some limitations that need to be addressed. Firstly, the sample of the study consisted of 758 teachers who were actively involved in distance education in spring semester of the 2019-2020 academic year in Turkey during the COVID-19 pandemic. Therefore, findings of this study provides empirical evidence from Turkish context. In future studies, cross-cultural studies in which teachers' opinions about and self-efficacy 
beliefs towards distance education can be compared and differences among countries can be examined, if any. Another limitation of the study is related to the data collection process. The data of the study relies solely on teachers' self-report responses to the online questionnaire which included mostly closed-ended items and one open-ended question. In future studies, in addition to the questionnaire, interviews can be conducted with teachers which may provide in-depth information about their experiences in distance education.

\section{BIODATA and CONTACT ADDRESSES of AUTHORS}

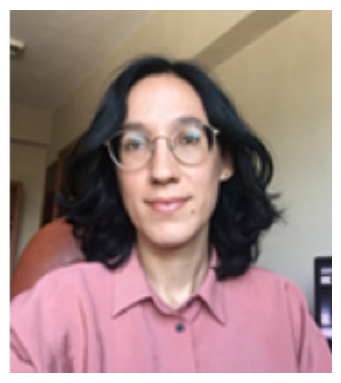

Dr. Yasemin TAS is an associate professor at the Department of Mathematics and Science Education at Kazim Karabekir Faculty of Education in Ataturk University. Dr. Tas gained her Ph.D. in Science Educational at June, 2013 from Middle East Technical University. Her academic interest areas are students' motivation, selfregulation, and engagement in science learning, science learning environment, teachers' self-efficacy beliefs, and design-based science instruction. She has journal articles published in journals with international and national indexes, book chapters and, papers presented at international and national meetings.

\section{Yasemin TAS}

Department of Mathematics and Science Education, Kazim Karabekir Faculty of Education Address: Ataturk University, 25240, Erzurum, Turkey

Phone: +90 4422314034

E-mail: tasyase@gmail.com

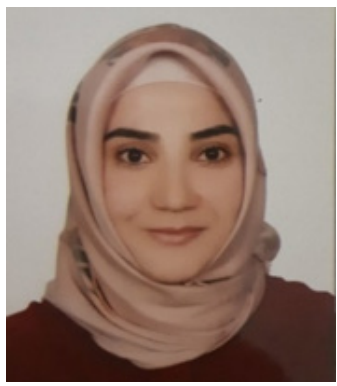

Selma EMINOGLU is a science teacher at the Ministry of Education. Eminoglu has been a Ph.D. student in Science Education since July, 2019 at Ataturk University. Her academic interests include the use of science concepts in religious education, science education, interdisciplinary teaching, misconceptions, distance education, and the use of microscopes in the laboratory. She has journal articles published in journals with international and national indexes, and papers presented at international meetings.

Selma EMINOGLU

Ministry of Education

Address: Ministry of Education, 04100, Agri, Turkey

Phone: +90 4422315635

E-mail: selmaemingl@gmail.com

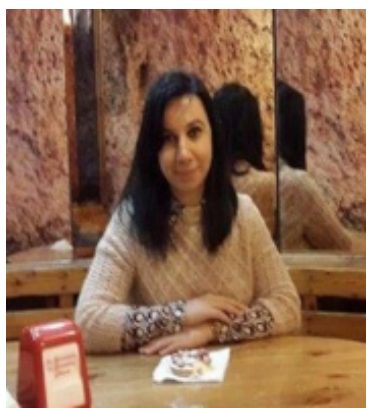

Gulsah ATILA works as a science teacher at the Ministry of National Education. She was accepted to the doctoral program in 2019. She is still continuing her doctoral education. Her academic interests are teaching science to visually impaired students, augmented reality, distance education, students with learning difficulties, the features that should be found in the theoretical and theoretical framework. The researcher has articles published in national and international journals and papers presented in national congresses.

Gulsah ATILA

Ministry of Education

Address: Ministry of Education, 25070, Erzurum, Turkey

Phone: +90 4422315635

E-mail: gulsahatilla@gmail.com.tr 


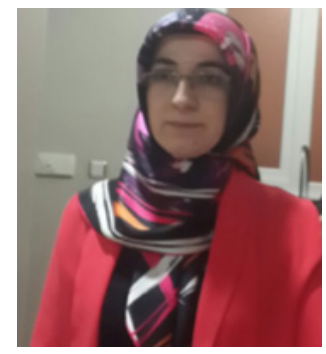

Yasemin YILDIZ completed her undergraduate education at Ataturk University at June, 2004. The researcher is a Ph.D. student at the Department of Mathematics and Science Education at Kazim Karabekir Faculty of Education in Ataturk University. Yasemin Yildiz works as a chemical engineer at the Erzurum Public Health Laboratory of the Ministry of Health.

Yasemin YILDIZ

Department of Mathematics and Science Education, Kazim Karabekir Faculty of Education Address: Ataturk University, 25240, Erzurum, Turkey

Phone: +90 4422342354

E-mail: yaseminyildiz12@hotmail.com

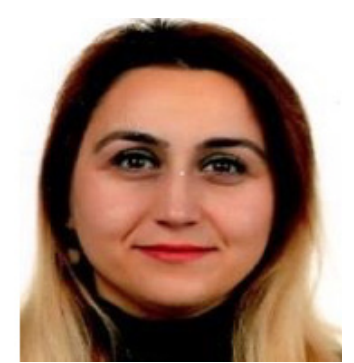

Ummugulsum BOZKURT is a Ph.D student at the Department of Mathematics and Science Education at Kazim Karabekir Faculty of Education in Ataturk University. Researcher Bozkurt completed her undergraduate education at Ataturk University at June, 2014. She completed her master's degree at Erzincan Binali Yildirim University at July, 2019. Her academic interest areas are learning methods, social network analysis, measuring attitude, distance learning, and science education. She has journal articles published in journals with international index.

Ummugulsum BOZKURT

Department of Mathematics and Science Education, Kazim Karabekir Faculty of Education Address: Ataturk University, 25240, Erzurum, Turkey

Phone: +90 4422315635

E-mail: gulsum.bozkurt09@gmail.com

\section{REFERENCES}

Allinder, R. M. (1995). An examination of the relationship between teacher efficacy and curriculum based measurement and student achievement. Remedial \& Special Education, 27, 141-152.

Almaiah, M. A., Al-Khasawneh, A., \& Althunibat, A. (2020). Exploring the critical challenges and factors influencing the E-learning system usage during COVID-19 pandemic. Education and Information Technologies, 1, 1-20.

Anadolu University (2021). Acikogretim sistemi [Open education system]. Retrieved from https://www. anadolu.edu.tr/acikogretim/acikogretim-sistemi/tarihce

Arbaugh, J. B. (2000). Virtual classroom characteristics and student satisfaction with internet based MBA couses. Journal of Management Education, 24, 32-54.

Armstrong-Coppins, D. R. (2003). What principals do to increase collective teacher efficacy in urban schools. (Unpublished doctoral dissertation). Cardinal Stritch University College of Education. Available from ProQuest Dissertations and Thesis database. (UMI No: 3119769).

Ashton, P. (1984). Teacher efficacy: A motivational paradigm for effective teacher education. Journal of Teacher Education 35(5), 28-32.

Aydin, M. (2017). Uzaktan ogretici yeterliliklerinin ve yeterlilik boyutlarinin belirlenmesi [Determination of distance instructors competencies and competency dimensions]. (Master's dissertation). Karadeniz Technical University Graduate School of Educational Sciences, Trabzon, Turkey. Available from the Council of Higher Education, National Dissertation Center, Dissertation ID: 472008. 
Baired, K. (2020). Caring for educators is the first step in serving students. Retrieved from https://thejournal. com/articles/2020/05/19/caring-for-educators-is-the-first-step-in-serving-students.aspx

Bakioglu, B., \& Cevik, M. (2020). COVID-19 pandemisi surecinde fen bilimleri ogretmenlerinin uzaktan egitime iliskin gorusleri [Science teachers' views on distance education in the COVID-19 pandemic process]. Turkish Studies, 15(4), 109-129.

Bandura. A. (1986). Social foundations of thought and action: A social cognitive theory. New Jersey: Prentice Hali.

Bandura, A. (1997). Self-efficacy: The exercise of control. New York: W. H. Freeman and Company.

Bandura, A. (1999). Social cognitive theory: An agentic perspective. Asian Journal of Social Psychology, 2(1), 21-41.

Basilaia, G., \& Kvavadze, D. (2020). Transition to online education in schools during a SARS-CoV-2 Coronavirus (COVID-19) Pandemic in Georgia. Pedagogical Research, 5(4), em0060. https://doi. org $/ 10.29333 / \mathrm{pr} / 7937$

Basaran, M., Dogan, E., Karaoglu, E., \& Sahin, E. (2020) Koronavirus (COVID-19) pandemi surecinin getirisi olan uzaktan egitimin etkililigi uzerine bir calisma [A study on effectiveness of distance education, as a return of coronavirus (COVID-19) pandemic process]. Academia Egitim Arastirmalari Dergisi, 5(2), 179-209.

Bayburtlu, Y. S. (2020). Covid-19 pandemi donemi uzaktan egitim surecinde ogretmen goruslerine gore Turkce egitimi [Turkish education during covid-19 pandemic distance education process]. Electronic Turkish Studies, 15(4), 131-151.

Bicer, H. (2019). E- ogrenmeye yonelik tutum: Olcek uyarlama calismasi [Attitudes towards e-learning: Scale adaptation]. (Master's dissertation). Necmettin Erbakan University Graduate School of Educational Sciences, Konya, Turkey. Available from the Council of Higher Education, National Dissertation Center, Dissertation ID: 557168.

Blonder, R., Jonatan, M., Bar-Dov, Z., Benny, N., Rap, S., \& Sakhnini, S. (2013). Can You Tube it? Providing chemistry teachers with technological tools and enhancing their self-efficacy beliefs. Chemistry Education Research and Practice, 14(3), 269-285.

Caprara, G. V., Barbaranelli, C., Steca, P. \& Malone, P. S. (2006). Teachers' self-efficacy beliefs as determinants of job satisfaction and students' academic achievement: A study at the school level. Journal of School Psychology, 44(6), 473-490.

Compeau D. R., \& Higgins C. A., (1995), Computer self-efficacy: Development of a measure and initial test, MIS Quarterly, 19(2), 189-211.

Creswell, J. W. (2011). Educational research: Planning, conducting, and evaluating quantitative and qualitative research (4th Ed.). London: Pearson.

Cakin, M., \& Kulekci Akyavuz, E. (2020). Covid-19 sureci ve egitime yansimasi: ogretmen goruslerinin incelenmesi. International Journal of Social Sciences and Education Research, 6(2), 165-186.

Cakiroglu, E., \& Isiksal, M. (2009). Preservice elementary teachers' attitudes and self-efficacy beliefs toward mathematics. Education and Science, 34(151), 132-139.

Calik, C. (2007). Okul cevre iliskisinin okul gelistirmedeki rolu: kavramsal bir cozumleme [The role of school-environment relation in school improvement: A conceptual analysis]. Gazi Universitesi Gazi Egitim Fakultesi Dergisi, 27(3), 123-140.

Cukadar, S., \& Celik, S. (2003). Internete dayali uzaktan ogretim ve universite kutuphaneleri [Web-based distance learning and university libraries]. Dogus Universitesi Dergisi, 4(1), 31-42.

De Witt, P. (2020) 6 Reasons Students aren't Showing Up for Virtual Learning. Retrieved from http://blogs. edweek.org/edweek/finding_common_ground/2020/04/6_reasons_students_arent_showing_ up_for_virtual_learning.html?intc=main-mpsmvs 
Digital Transformation Office (2021). Koronavirus COVID-19 dunya haritasi [Coronavirus COVID -19 world map]. Retrieved from https://corona.cbddo.gov.tr/

Ertan Kantos, Z. (2020). Sinif ogretmenlerinin uzaktan egitim ile ilgili dusunceleri. K. Ciftyildiz, 8. Uluslararasi Bilimsel Arastirmalar Kongresi Bildiri Tam Metin Kitabi icinde (ss. 65-81). Corum: Asos Yayinevi.

Fagell, P. L. (2020). Career Confidential: Teacher wonders how to help students during coronavirus shutdown. Phi Delta Kappan, 101, 67-68.

Galusha, J. M. (1998). Barriers to learning distance education. Universty of Southern Missisipi.

Gibson. S., \& Dembo, M. H. (1984). Teacher efficacy: A construct validation. Journal of Educational Psychology, 76(4). 569-582.

Hens, N., Ayele, G. M., Goeyvaerts, N., Aerts, M., Mossong, J., Edmunds, J. W., \& Beutels, P. (2009). Estimating the impact of school closure on social mixing behaviour and the transmission of close contact infections in eight European countries. BMC Infectious Diseases, 9(187), 1-12.

Holmberg, B. (1995). Theory and practice of distance education. New York: Routhledge.

Isik, I., Isik, A. H., \& Guler, I. (2008). Uzaktan egitimde uc boyutlu web teknolojilerinin kullanilmasi [Using the 3D web technologies in distance education]. Bilisim Teknolojileri Dergisi, 1(2), 75-78.

Iwai, Y. (2020). Online Learning during the COVID-19 Pandemic: What do we gain and what do we lose when classrooms go virtual?', Scientific American. https://blogs.scientificamerican.com/observations/ online-learning-during-the-COVID-19-pandemic/

Joreskog, K., \& Sorbom, D. (2007). LISREL 8 User's Guide. Chicago: Scientific Software.

Kaden, U. (2020). COVID-19 school closure-related changes to the professional life of a K-12 teacher. Education Sciences, 10(165), 1-13.

Kaya, Z. (2002). Uzaktan egitim [Distance education]. Ankara: Pegem A Yayinlari.

Kirik, A. M. (2014). Uzaktan egitimin tarihsel gelisimi ve Turkiye'deki durumu [Historical development of distance education and the situation in Turkey]. Marmara Iletisim Dergisi, 21, 73-94.

Košir, K., Dugonik, Š., Huskić, A., Gračner, J., Kokol, Z., \& Krajnc, Ž. (2020). Predictors of perceived teachers' and school counsellors' work stress in the transition period of online education in schools during the COVID-19 pandemic. Retrieved from https://psyarxiv.com/gj3e5/

Larrick, C. S. (2004). Collective teacher efficacy and student achievement. (Unpublished doctoral thesis). Universty of Virginia. Available from ProQuest Dissertations and Thesis database. (UMI No: 3144628).

Lee M. H., \& Tsai C. C., (2010), Exploring teachers' perceived self efficacy and technological pedagogical content knowledge with respect to educational use of the World Wide Web, Instructional Science, $38,1-21$.

Ministry of Education (2020a). Retrieved from http://www.meb.gov.tr/

Ministry of Education (2020b). Retrieved from http://uzaktanegitim.meb.gov.tr/www/bilgilendirmevideolari/kategori/12

Murray, C. (2009). Parent and teacher relationships as predictors of school engagement and functioning among low-income urban youth. The Journal of Early Adolescence, 29(3), 376-404.

Pirtle, W. N. L. (2020). Racial capitalism: A fundamental cause of novel coronavirus (COVID-19) pandemic inequities in the United States. Health Education \& Behavior, 47(4), 504-508.

Merrill, S. (2020). Teaching through a Pandemic: A Mindset for This Moment. Retrieved from https://www. edutopia.org/article/teaching-through-pandemic-mindset-moment

Midgley, C., Feldlaufer. H., \& Eccles, J. S. (1989). Change in teacher efficacy and student self- and task related beliefs in mathematics during the transition to junior high school. Journal of Educational Pschology, 81(2), 247-258. 
Ozbay, O. (2015). Dunyada ve Turkiye'de uzaktan egitimin guncel durumu [The current status of distance education in the world and Turkey]. Uluslararasi Egitim Bilimleri Dergisi 2(5), 376-394.

Ozer, B. (1999). Uzaktan egitim sisteminin evrensel yapisi [Universal structure of the distance education system]. Kurgu Dergisi, 8, 569-594.

Ross, J. A. (1994). The impact of an inservice to promote cooperative learning on the stability of teacher efficacy. Teaching and Teacher Rducation, 10(4), 381-394.

Sahu, P. (2020). Closure of universities due to coronavirus disease 2019 (COVID-19): Impact on education and mental health of students and academic staff. Cureus, 12(4). doi: 10.7759/cureus.7541

Saklan, H., \& Unal C. (2019). Dijital egitim platformlari arasinda EBA'nin yeri ile ilgili Fen Bilimleri ogretmenlerinin gorusleri [Opinions of science teachers on the status of EBA among digital education platforms]. Ondokuz Mayis Universitesi Egitim Fakultesi Dergisi, 38(1), 19-34.

Schneider, S. L., \& Council, M. L. (2020). Distance learning in the era of COVID-19. Archives of Dermatological Research, 1. https://doi.org/10.1007/s00403-020-02088-9

Talidong, K. J. B., \& Toquero, C. M. D. (2020). Philippine teachers' practices to deal with anxiety amid COVID-19. Journal of Loss and Trauma, 25(6-7), 573-579.

Tschannen-Moran, M., \& Woolfolk Hoy, A. (2001). Teacher efficacy: Capturing an elusive construct. Teaching and Teacher Education, 17(7), 783-805.

Tschannen-Moran, M., \& Woolfolk-Hoy, A. (2007). The differential antecedents of self-efficacy of novice and experienced teachers. Teaching and Teacher Education, 23, 944-956.

Tschannen-Moran, M., Woolfolk Hoy, A., \& Hoy, W. K. (1998). Teacher efficacy: Its meaning and measure. Review of Educational Research, 68(2), 202-248.

Tuckman, B. W., \& Sexton, T. L. (1990). The relation between self-beliefs and self-regulated performance. Journal of Social Behavior and Personality, 5(5), 465-472.

UNESCO (2020a). SDG-Education 2030 Steering Committee Urges Protection of Education, now and postcrisis. Retrieved from https://sdg4education2030.org/sdg-education-2030-steering-committeeurges-protection-education-now-and-post-crisis

United Nations Educational, Scientific and Cultural Organization [UNESCO] (2020b). How to keep Engaged Remotely with Your Students in the Context of the COVID-19 Crisis: TipforTeachers. https:// en.unesco.org/news/resources-parents-and-teachers-motivating-supportingchildren-duringremote-learning.

Ustun, A. B., Karaoglan Yilmaz, F. G., \& Yilmaz, R. (2020). Ogretmenler e-ogrenmeye hazir mi? Ogretmenlerin e-ogrenmeye yonelik hazir bulunusluklarinin incelenmesi uzerine bir arastirma [Are teachers ready for e-learning? A study on exploring e-learning readiness of teachers]. Ahmet Kelesoglu Egitim Fakultesi Dergisi, 2(1), 54-69.

Van Lancker, W., \& Parolin, Z. (2020). COVID-19, school closures, and child poverty: A social crisis in the making. The Lancet Public Health, 5, e243-e244.

Varol, A. (2001). YOK Enformatik Milli Komitesinin gorevleri ve Turkiye'de uzaktan egitim. Sakarya Universitesi Egitim Fakultesi Dergisi, 3, 41-53. Retrieved from https://dergipark.org.tr/en/ download/article-file/115823

Viner, R. M., Russell, S. J., Croker, H., Packer, J., Ward, J., Stansfield, C., ... \& Booy, R. (2020). School closure and management practices during coronavirus outbreaks including COVID-19: A rapid systematic review. The Lancet Child \& Adolescent Health, 4(5), 397-404.

Wang, C., Cheng, Z., Yue, X.-G., \& McAleer, M. (2020). Risk Management of COVID-19 by universities in China. Journal of Risk and Financial Management, 13(36), 1-6.

Winter, L. (2020). I'm a teacher in Italian quarantine, and e-learning is no substitute for the real thing. Retrieved from https://www.theguardian.com/commentisfree/2020/mar/18/italy-quarantine-e-learningcoronavirus-schools-lockdown-teaching-children 
Woolfolk, A. E., Rosoff, B., \& Hoy, W. K. (1990). Teachers' sense of efficacy and their beliefs about managing students. Teaching and Teacher Education, 6(2), 137-148.

Telli Yamamoto, G. T., \& Altun, D. (2020). Coronavirus ve cevrimici (online) egitimin onlenemeyen yukselisi [The coronavirus and the rising of online education]. Universite Arastirmalar Dergisi, 3(1), 25-34.

Yang, X. (2020). Teachers' Perceptions of Large-Scale Online Teaching as an Epidemic Prevention and Control Strategy in China. ECNU Review of Education, 1-6. doi: 10.1177/2096531120922244

Yerli, M. S. (2018). Sosyal bilgiler ogretiminde Egitim Bilisim Agi (EBA) uygulamasinin ogrencilerin akademik basarisina etkisi [Education Information Network (EBA) of the application of social studies in teaching students academic success of the effect of]. Master's dissertation). Adiyaman University Graduate School of Educational Sciences, Adiyaman, Turkey. Available from the Council of Higher Education, National Dissertation Center, Dissertation ID: 508960.

Yildiz, M. (2015). Uzaktan egitim programlarinda ders veren ogretim elemanlarinin uzaktan egitime yonelik bilgi, inanc ve uygulamalari arasindaki iliskiler [The relationships among distance education instructors' knowledge, belief and practices towards distance education]. (Master's dissertation). Hacettepe University Graduate School of Educational Sciences, Ankara, Turkey. Available from the Council of Higher Education, National Dissertation Center, Dissertation ID: 394811.

Yilmaz, M. (2020). Uzaktan egitimin iyilestirilmesi: Salgin kaynakli egitim krizini asmak icin oneriler [Improving distance education: recommendations for overcoming the epidemic education crisis]. Istanbul: ILKE Ilim Kultur Egitim Vakfi. 


\section{APPENDIX}

\section{Questions in the Third Part of the Questionnaire}

1. Sinifinizdaki ogrencilerin yuzde kaci canli derse (sanal sinif/cevrimici ders) katiliyor?

[What percentage of students in your class attend the live class (virtual classroom/online class)?]
$\% 1-\% 25$
$\% 26-\% 50$
$\% 51-\% 75$
$\% 76-\% 100$

(Canli derse katilan ogrenci sayisinin az oldugunu dusunuyorsaniz 2. soru ile devam ediniz, dusunmuyorsaniz 3. soruya geciniz.)

[(If you think the number of students attending the live class is insufficient, continue with question 2, if not, continue with question 3.)]

2. Canli derslere katilan ogrenci sayisinin sinif mevcudundan az olmasi ogretmen olarak motivasyonunuzu olumsuz etkiliyor mu?

[Does the fact that the number of students attending live classes is less than the class size negatively affect your motivation as a teacher?]
Evet [Yes]
Hayir [No]

3. Size gore canli ders icin en uygun saat dilimi hangisidir?

[In your opinion, what is the best time for live classes?]
07-09
09-11
$11-13$
$13-15$
$15-17$
$17-19$
$19-21$
$21-23$

4. Canli derste karsilastiginiz teknik problemleri cozmek icin kurumunuzdan herhangi bir destek aliyor musunuz?

[Do you get any support from your institution to solve the technical problems you encounter in the live classes?]
Evet [Yes]
Hayir $[\mathrm{No}]$

5. Canli ders sayesinde her durumda rahatca sinif ortami olusturup ders isleyebileceginizi dusunuyor musunuz?

[Do you think that you can easily create a classroom environment and teach through the live classes?]
Evet [Yes]
Hayir [No]

6. Uzaktan egitimde olcme ve degerlendirmeyi etkili olarak gerceklestirebiliyor musunuz?

[Can you effectively perform assessment and evaluation in distance education?]

$\square$ Evet [Yes] $\square$ Hayir [No]

7. Size gore ders konulariniz, canli ders ile islenmeye uygun mu?

[In your opinion, are your class subjects suitable to be taught with live classes?]

$\square$ Evet [Yes] $\square$ Hayir [No]

8. Uzaktan egitim alan ogrencilerin basarili olabilmeleri icin platformdaki mevcut ders materyalleri ile calismalarinin yeterli oldugunu dusunuyor musunuz?

[Do you think that it is sufficient for distance education students to work with the current instructional materials on the platform in order to be successful?]
$\square$ Evet [Yes]
Hayir $[\mathrm{No}]$

9. Canli derslerin ogrencilerin anlamli ogrenmesine katki sagladigini dusunuyor musunuz?

[Do you think that live classes contribute to students' meaningful learning?]

$\square$ Evet [Yes] $\square$ Hayir [No] 
10. Mevcut uzaktan egitim sistemini egitsel acidan basarili buluyor musunuz?

[Do you find the current distance education system to be educationally successful?]

$\square$ Evet [Yes]

Hayir $[\mathrm{No}]$

11. Uzaktan egitim size ekonomik bir yuk getirdi mi?

[Has distance education placed an economic burden on you?]
Evet [Yes]
Hayir [No]

12. Bilgisayar sistemi ile etkilesimi sinir bozucu buluyor musunuz?

[Do you find the interaction via the computer system annoying?]

$\square$ Evet [Yes] $\square$ Hayir [No]

13. Canli derslerle islediginiz dersin yuz yuze egitimdeki kadar verimli oldugunu dusunuyor musunuz? [Do you think the lessons you teach with live classes are as efficient as in face-to-face education?]
Evet [Yes]
Hayir [No]

14. Canli ders ile ders islemeyi, yuz yuze egitimle ders islemeye gore daha zevkli buluyor musunuz?

[Do you find it more enjoyable to teach with live classes than with face-to-face education?]

$\square$ Evet [Yes] $\quad \square$ Hayir [No]

15. Pandemi doneminden once teknolojiyi derslerinizde aktif olarak kullaniyor muydunuz?

[Did you use technology actively in your classes before the pandemic period?]

$\square$ Evet [Yes] $\square$ Hayir [No]

16. Pandemi surecinde uzaktan egitim konusunda edindiginiz deneyimlerin egitimdeki verimliliginizi arttirdigini dusunuyor musunuz?

[Do you think your experiences in distance education during the pandemic period increased your efficiency in education?]

Evet [Yes]

Hayir $[\mathrm{No}]$

17. Uzaktan egitim surecinde velilerden yeterli destek gordunuz mu?

[Did you receive sufficient support from parents in the distance education process?]

Evet [Yes] $\square$ Hayir [No]

18. Uzaktan egitim surecinde okul yonetiminden yeterli destek gordunuz mu?

[Did you receive sufficient support from the school administration during the distance education process?]
Evet [Yes]
Hayir [No]

19. Uzaktan egitim deneyimleriniz ile ilgili eklemek istediginiz baska bir sey varsa lutfen yaziniz. [Please write if there is anything else you want to add about your distance education experiences.] 